\title{
MAKEING A PLAN OF BIOSECURITY ON A CATTLE FARM
}

\author{
Atanas Nitovski, Milinko Milenković, Bisa Radović, Valentina Milanović, \\ Dragan Grčak, Milovan Grčak \\ Agriculture Faculty, Lesak, Kosovo and Metohia, Serbia \\ anitovski@gmail.com
}

\begin{abstract}
On a farm infectious diseases may occur by introducing infected animals, introduction of cattle in the incubation period, carcasses of animals that were not removed properly, vehicles, equipment, clothing and shoes of visitors or employees who have contact with other herds, more often contact with the herd, contact with other animals (horses, dogs, cats, wildlife, rodents, birds, insects), but also by contaminated objects, contaminated food, and improper management of manure when it comes to the creation of dust and scattering (Hristov, 2007). To prevent introduction of infection to the farm or farms in the environment, we use primary and secondary Biosafety measures. The most effective implementation of biosecurity measures on farms provides a development plan for that farm biosecurity. We have developed the biosecurity plan based on detailed observation and analysis of the relevance of indicators and on biosecurity which includes: 1 . Making and submitting a written plan for achieving and maintaining biosecurity on farm production based on keeping proper records; 2. Isolation of he farm as a whole or individual segments of manufacturing and production operations; 3 . Introduction of newly acquired animals in a herd; 4. Health of the herd; 5. Evaluations of the personnel and the equipment; 6 . Traffic and movement control; 7. Attitude towards visitors; 8. Control of food and water; 9. Manure; 10. Disposal of carcasses of dead animals; 11. Relationship to other animals on the farm; 12. Population control of rodents and birds; 13. Sanitation (Stanković et al,, 2010).
\end{abstract}

Key words: Biosecurity plan; farm; cattle; dairy cows

\section{ИЗРАБОТКА НА ПЛАН ЗА БИОСИГУРНОСТ НА ФАРМА ЗА ГОВЕДА}

\begin{abstract}
Причините за појава на заразни болести на фарма можат да бидат внес на заразени животни, внес на добиток во период на инкубација, трупови на животни кои не се отстранети правилно, возила, опрема, облека и обувки на посетители или вработени кои имаат контакти со други стада, почести контакти со стадото, контакти со други животни (коњи, кучиња, мачки, диви животни, глодари, птици, инсекти), но и контаминирани предмети, загадена храна, како и неправилно управување со изметот кога станува збор за создавање прашина и расејување (Христов, 2007). За да се спречи внесот на инфекции на фармата/фармите, во животната средина ги користиме основните и средните биосигурносни мерки. Најефикасна имплементација на биосигурносните мерки на фармите е обезбедување на план за развој на биосигурност на фарма. Планот на биосигурноста го имаме развиено врз основа на детални набљудувања и анализа на релевантноста на индикаторите и на биосигурноста. Тој план ги вклучува следните поглавја: 1) Постоење и поднесување план за постигнување и одржување биосигурност на производството на фармата врз основа на водење соодветна евиденција. 2) Изолација на фармата како целина или на одделни сегменти на производство и производните операции. 3) Воведување на новонабавени животни во стадото. 4) Здравје на стадото. 5) Процени на персоналот и на опремата. 6) Контрола на сообраќајот и движењето. 7) Однос кон посетителите, 8) Контрола на храната и водата. 9) Ѓубриво. 10) Отстранување на труповите на мртви животни. 11) Однос кон другите животни на фармата. 12) Контрола на популацијата глодари и птици. 13) Санитација (Станковиќ и сор., 2010).
\end{abstract}

Клучни зборови: биосигурносен план; фарма; говеда; млечни крави

\section{INTRODUCTION}

The concentration of a large number of individuals in a relatively small area is one of the key features of intensive production, making it neces- sary to apply certain measures to safeguard animal health, to prevent the introduction and spread of diseases and preservation of production. Work on the formulation and implementation of biosecurity plans involves sustained commitment to creating 
and maintaining a satisfactory living environment for animals and their production (Stanković et al., 2007).

In developing specific biosecurity plans, we took into account the necessary level of herd health status, organization, scope and type of production on the farm, predicted all measures necessary to control the herd health status and prevent the introduction and spread of infectious diseases, especially those whose existence must be reported. These diseases are listed in the program of animal health protection measures for the Republic of Serbia in 2012. It must also be taken into account the current epizootic situation and anticipate potential threats to health and production on the farm and possible solutions. Biosecurity plan should contain a commitment to efficient and regular cleaning and disinfecting parts of farms where animals live.

In developing biosecurity plan we used: 1) Rules on determining the program of animal health protection measures for 2012 (Official Gazette of the Republic of Serbia, $\mathrm{N}^{\circ}$. 21/12), 2) Biosecurity standards-setting basic biosecurity plans, brochure - Ministry of Agriculture, Trade, Forestry and Water Management for Animal Health, 3) Ordinance on veterinary sanitation facilities for breeding and ungulate, ungulates, birds and rabbits (Official Gazette of the Republic of Serbia, N $\left.{ }^{\circ} .81 / 2006\right)$, 4) Principles of biosecurity at farm-Design guide for biosecurity plans of the Ministry of Agriculture, Fisheries and Rural Development-Veterinary Administration of the Republic of Croatia, 2011 $1^{\text {th }}$.

In this paper, we also used to supplement the program of measures and standards biosecuritynext works: 1) Biosecurity Plan for Australian Dairy industry; 2) Biosequrity: Health Protection and Sanitation Strategies for Cattle and General Guidelines for Other Livestock of Ministry of Agiculture Food \& Rural Affairs in Ontario; 3) Biosequrity for Dairy Facilites from Animal Health Information of the Department of Agricultural Resources, Division of Animal Health, Boston, MA.USA.

\section{EXPERIMENTAL SECTION}

In a previous paper on biosafety and biosecurity measures, analysis of these measures, we performed an example of a large modern dairy farm near Belgrade. By analyzing the presence, absence of certain biosecurity measures on the farm we found absence of the disinfection barrier, facilities for receiving, viewing and storage of dead animals were not provided, pit graves for elimination of placentas were not provided as well as adequate protection against rodents (rats and mice) and setting up a triple ring of vessels with near-rodenticides outside fence, outside around the building and its facilities. The farm Management in consultation with the management company agreed that for such a serious production such as theirs, it was necessary to develop a biosecurity plan that would ensure the full and comprehensive implementation of biosecurity measures.

The cow farm, for which we did the biosecurity plan is in the vicinity of Belgrade in a location that is in accordance with veterinary sanitary conditions prescribed by the Ordinance on veterinary sanitation facilities for breeding, ungulates, birds and rabbits (Official Gazette RS, $\mathrm{N}^{\circ}$. 81/2006). The farm is built upon the previously approved plan for the building in which the objects are constructed according to the technological needs of the planned production, respecting the principles of construction of modern facilities for keeping milk cows and their offspring. The livestock production sector is divided into four departments:

1) Department - cluster center (under whose jurisdiction are the main dairy cows and milking parlor).

2) Department - reprocenters (breeding female breeding offspring from 1-20 months).

3) Department - for feed and food (production and forage-concentrate feed mixers, food and supplies on the farm).

4) Department - small parlor (highly pregnant heifers, dry cows, maternity hospital, which is related to the little parlor).

The Department selects the records and keeps track of all the common farm departments.

The farm has about 1,500 cows and 1,200 head of breeding female offspring. The cows were Holstein-Friesian and placed in the appropriate production facilities-barns that are divided and arranged as a barn for milking cows and more small-scale, dry cows in barns, stables, maternity and sick cows, barns for high-calf heifers, barns for heifers with larger and smaller capacity, stables for cattle.

The farm has the necessary pit silos for silage making, the appropriate number of hay-storage accommodation and clover hay, feed mixers of adequate capacity and the required number of silos 
for storing grains as ingredients for the production of concentrated food. On the farm there are two plateaus with igloos to accommodate calves up to one month; lactic rotary milking parlor type with 60 seats; milking parlor herringbone type with $2 \times 8$ seats, clothes for workers on the farms with a laundry room, bathroom and toilet; a weighbridge; facilities for veterinary service, administrative buildings, workshops, a lagoon $400 \times 50 \times 5 \mathrm{~m}$, a lagoon $160 \times 18 \times 5 \mathrm{~m}$;

\section{RESULTS AND DISCUSSION}

The biosecurity plan was prepared as recommended by the Ministry of Agriculture contained in the brochure on-farm biosecurity standardssetting basic biosecurity plans and the Regulation on establishing the program of animal health protection measures for 2012. The biosecurity plan includes consideration of the user activities in the following technological processes:

\section{Existing and setting of a written plan for achieving and maintaining biosecurity of the farm production based on keeping proper records}

A written biosecurity plan includes keeping required records, such as keeping data on the treatment of animals-and outpatient withdrawal protocol, conducted data on mortality of animals, record keeping on putting animals on the market, management of monitoring data by the farm veterinary inspectorate. It is necessary to keep daily record required as a prerequisite for monitoring and controlling the implementation of the biosecurity plan. Planning activities on the farm include not only the introduction of new animals to the farm, but also moving animals (eg, switching from the waiting place to the maternity ward, in the Service center), placing the animals on the market, and all this must be considered and the necessary records must be taken.

\section{Isolation of farm as a whole or individual segments of manufacturing and production operations}

Isolation involves housing animals in special facilities. The animals returned to the farm from where they were in contact with other animals (e.g. exhibitions, fairs) should be isolated at least for two weeks. If it is impossible to achieve complete isolation, the animals need to be isolated using partitions in the same building, or to prevent direct contact between animals, and it is particularly important not to allow healthy animals or animals that are not quarantined to use their feeders and drinkers. Clothing and footwear worn by workers in the facility where animals are housed in isolation, need to be changed before entering the premises with animals that are not in isolation. Animals showing signs of illness and before you call the vet should be isolate as soon as possibleo.

\section{Introduction of newly acquired animals in a herd}

The introduction of new animals in the herd is usually done by the selection of reasons such as to fill the number of animals, acquisition of new bulls and heifers for "Blood Fire" and others. When receiving newly acquired animals quarantine accommodation should be organized for these animals. The quarantine means wearing special clothing and footwear, which the worker must not wear into other productive areas. He subscribes to daily health situation and keeps records. The length of quarantine is about 28 days, or two times of average duration of disease incubation of 14 days. On the farm there is a corresponding number of objects in them where quarantine can be organized.

\section{Health of the herd}

On a large farm or farms in general it is necessary to have daily monitoring of animal health. The health status is monitored by direct inspection of the conditions during daily visits to the farm during the "visit" and veterinary inspection of records, or records of mortality and the record of treatment of animals on the farm. Therefore, there is a necessity of daily changes in the appropriate input records. Changes in the health status are evident changes in production, with a decline in production results. The smaller the increment, the weaker is entering estrus, there is an extension of service period, increased number of dead animals. When the clinical signs of disease recognized are there is a change in the behavior of animals, they become agitated, timid, or irritable with uncoordinated movement. Changing health leads to changes in food intake and water. It leads to lower food intake and a greater need for water intake, which is 
used in the treatment of young animals with medicaments or drugs dissolved in water with a vitamin mineral supplement. It is necessary in cooperation with your veterinarian to develop a plan of action when there are suspicions of an infective disease which should include description of the situation in which you plan to react to the phenomenon where a large number of animals show signs of illness. When there is no significant decrease in production or when the usual therapeutic procedures do not provide adequate results, or do not result in visible improvement of the animal health, and there is a large number of deaths. Youshould use the recorded telephone numbers of persons who in such situations should be invited to contact you or call veterinarians, farm managers, veterinary inspectors, veterinarians from the Veterinary Institute, professors of Veterinary and Agricultural Faculty. The plan should include restriction of movement of animals and people and vehicles on the farm. This means reduced sales of animals, buying new animals, but also reduced required amount of food and so on. Other measures recommended by the veterinary services in collaboration with colleagues from the Veterinary Institute, which covers this epizootiological cow farm are also undertaken.

\section{The ratio of staff to the equipment}

The farm is fully equipped for accommodation, food, feed, milking, manure, disinfection, treatment, transport, ventilation and other equipment that is aimed at the preservation of good health and good production results. Therefore, the daily inspection of the legality of this equipment is very important precondition for the realization of the biosecurity plan. Therefore it is necessary for the workers constantly to emphasize the importance of proper storage and maintenance of all equipment on the farm, and those with a bad attitude towards the equipment should be punished and the good ones to be rewarded.

\section{Control of movement and circulation}

Vehicular and pedestrian traffic is carried on the farm. Trucks come to the farm bringing food trucks that bring in new animals or transported animals, trucks that bring raw materials for food mixers, hay or silage for raw materials, trucks that transport dead animals or animals sent to slaughter economically. None of the vehicle can enter the farm if there is no confirmation of the disinfection in the veterinary station or other authorized institution and daily records should be taken on the entry of all vehicles. Care must be taken not to cross the roads clean and dirty on the farm, and that workers at the entry to the farm to go clothes "dirty", and the production facilities-a "clean" ways. The truck driver should be asked not to leave the vehicle or to move in the vicinity, where it is prohibited from entering the production facilities.

\section{Relationship to visitors}

Colleagues come to the farm from other farms, breeding animals, customers, buyers of beef, male animals which are excluded from breeding, organized visits of students of secondary schools and colleges, veterinarians from the Institute of Veterinary, veterinary inspectors, workers for service companies that perform pest and rodent control, etc. To enable the Farm to be an experimental source, space for training young professionals of different profiles of education, from high school, college students and young farmers and to build high-production and protection, we must strictly ensure that infectious material the farm has not entered and induced any infectious, parasitic, or organic disease. The farm should provide the required number of coats, disposable coveralls, boots, greaves, work clothes. Visitors to the farm get clean shoes and clean clothes, which is good for visitors to the farm to be provided with a disposable cover for clothing and footwear.

\section{Control of food and water}

The farm has its own food mixers in which the concentrated food is produced. Raw materials are transported in mixers with 4000 acres of its own country. The raw materials are stored in silos before being examined chemically and microbiologically in our own laboratory. The control of raw materials and finished products is made in laboratories of the Institute of Animal Husbandry in Zemun Polje. The mixers and dryers for corn grain, enable reducing the required moisture level. In addition to concentrated food, the farm produced silage of silage maize ripening in wax by adding Sudangrass and sorghum. I oversee the ensiling process and the quality of silage is controlled in our own laboratory and the Institute of Animal Husbandry. Lately, microorganisms which are 
added to the silage culture accelerate the ensiling period. In this way, the quality of silage is equalized and enhanced by providing a short time to establish the necessary concentration of acetic and propionic acid as preservatives. Excluding silage is done mechanically so that the uniformed exemption does not leave a large free area with no preservatives and development of butyric acid. Feeding roughage is done in the corridor for food, which is located in the middle of the stables and barn divided into two halves. The corridor is wide enough to allow dispensation of food mixers. Some cows can get the computer feeders that are in boxes. Cows were classified according to be product groups, milk production, the level of pregnancy, lactation stage and were given $10 \%$ more food than the norms.

Water supply is done by providing their own water from wells. The farm has four wells with water towers that provide the required amount of water for drinking, flushing system for milking, cleaning and disinfection facilities. Farm has a contract on business-technical cooperation with the Institute for Health Protection, which controls the quality of water for 15 days. Each well is secured with chloric apparate that automatically performs chlorination. The performed analyzes of food and water maintain separate records under the control of the veterinary inspection. Thus the farm has enough quality and hygienic food and water that provides a smooth development of young animals, a high milk yield and the reproductive performance.

\section{Manure}

The barns on the farm leagues have stalls with chopped mat. In the hospital there are stalls with mattresses. The boxes are in muddy corridors with width of about $2.20 \mathrm{~m}$. The muddy hallways are cleaned by moving machinery-scrapers, and their slope ranges from 1 to $2 \%$. Cross-cuts are made that reduce slipping of cows. At the end of the hallway there is a muddy channel cross manure. From the cross-channel sound goes to the plateau phase of the manure, a liquid in lagoons. The hard part is cleaned at least twice a year. There are lying stalls for cows and the increased length is for 2.20 to $2.40 \mathrm{~m}$, width of $1.20 \mathrm{~m}$. They are covered with chopped mat. Lagoons are periodically emptied when there is a free surface after removing their own crops (harvest, corn harvest, mowing clover). On the farm they began construction of biogas production from a mixture of liquid manure, silage and watter. Biogas will be used to produce electricity and steam production. Electricity will be included in the power system of Serbia, and steam production in flowers and vegetables in greenhouses. Using biomass from the liquid manure eliminates the environmental problem of unpleasant odors from lagoons, as $\mathrm{H}_{2} \mathrm{~S}, \mathrm{SO}_{2}, \mathrm{NO}_{2}$, burn the torches in the production of biogas.

\section{Disposal of carcasses of dead animals}

The farm has a small number of deaths that same day, driven to the pound in Padinska Skela. The problem is that the farm has no facilities for receiving, viewing and storage of dead animals being transported to the pound. The management of the farm has accepted the suggestion that in the investment for the biogas plant facilities for receiving, viewing and storage (freezing chamber) of corpses should be buitt as well. Samples for bacteriological examination of dead animals can be taken there too.

\section{Relationship to other farm animals}

The farm can not keep other animals than dogs who are tied near the farm fence and move along the fence with the chain.

\section{Control of rodent and bird populations}

During spring and summer months the farm has reduced the number of rats and mice who have moved to the fields around farms. There are beginning of rainy days increases the number of rodents. Eradication and fumigation are entrusted to a private company that is specialized in performing these tasks. There are small vessels with rodenticides, there are no vessels with liquid poison (e.g. Rosol), the vessels are not well distributed, and therefore there islacking in production facilities. We recommend a triple ring around the production facilities and food mixers. The first ring is next to the fence and should enable the first intake of poison beside the fence. The second ring has manufacturing facilities around the outside. The third ring is set up in the bowl to the objects themselves. We insisted on periodic changing of types of baits such as fish, cheese with dried meat products, always with food of animal origin, which does not 
have the recipe for the concentrated feed of dairy cows.

Cowshed are semi-open and free access to the birds. The diet of cows is silage based, to a large number in bunker silos, threshing barns and there is scattered food around feed mixers. Around the bunker silo workers are always present, and prevent contamination from food pecking and bird droppings.

\section{Sanitation}

Sanitation includes personal hygiene, cleaning and disinfecting materials, people and equipment entering the farm and hygiene of personnel and equipment on the farm. Disinfection is carried out in three steps: cleaning, washing and sanitary use of disinfection and disinfection solution. We insisted in the farm management on strict adherence to these procedures. When selecting funds, we proposed disinfectant funds with bactericidal and virucidal effects such as Virkon, Sporotal, Hibitane (Hlorhexidin gluconat). Quaternary ammonium compounds as Tego, Desu can be used at the entrance for hand washing. The trucks and pedestrian barriers should pour 3\% formaldehyde or $2 \% \mathrm{NaOH}$.

We insisted on dis-covering of the barrier to reduce evaporation from the dis-barrier and the impact of atmospheric dilution of the disinfectant. We suggested that in addition to disinfection barriers sprinkler wheels and lower trucks and trailers should be incorporated. In this way there is no influence of precipitation on the concentration of disinfectant agents, contamination and mixing of disinfectants with dust and mud to create a barrier and so on. We insisted that the door of the farm set a motor or an electric pump that would allow safe disinfection of vehicles entering the farm. The vehicle which does not possess a certificate of disinfection from a veterinary station or other authorized institution or organization can not enter the farm.

According to the program of animal health protection measures for 2012, the farm has done marking and registration of animals, implemented with Biosafety zoo-sanitary measures and animal welfare. Implemented measures imunoprophylactic (IBR), diagnostic tests (Tuberkullosis. Brucellosis, leucosis). Diagnostic tests are performed at abortion and keep records of abortions performed and diagnostic tests.
The farm within the implementation of biosecurity measures should determine the level of indicators of biosecurity. Indicators of biosecurity are the most sensitive places on our dairy farm. These are igloos for calves, maternity hospitals, a milking parlor. These facilities have been paid special attention because they expect the greatest impact of pathogenic microorganisms, parasites, viruses, molds and fungi.

Ministry of Agriculture of Canada in Ontario worked on biosecurity measures at the deli Biosafety safeguards against the entry of diseases on a farm, and measures of spread of disease. Protection against entry of diseases includes: Management of New Arrivals, Maintain a herd, Isolate new arrivals, Know the source of purchases and use of laboratory testing, Use vaccines.

Prevent the Spread of Diseases: Management of Farm Traffic Control of birds, rats and mice control, control of people and pets, vehicles, Control and traffic patterns on the farm, Control feed and feeding equipment, management of groups and housing, Sanitation and Disinfection Management Disposal of dead animals, manure Management and control flies, Management maternity, sick and calf pens, Use disifectants, Foreign Animal Diseases, Border Control, On-farm control, Disinfectants for Boot Wash.

Biosecurity Plan of Australian Dairy Industry in Measures for Reducing the risk of introducing infectious diseases includes: Introduced Stock, Vehicle/People Movement, Stockfeed, Boundaries, Feral Animal and Wildlife. Measures for Reducing the risk of spread of diseases on the farm contaun: Regular Monitor and Investigate Animal Illiness/ Death, Maintain Good Animal Management, Dead Animal Management, Effluent.

In Biosecurity for Dairy Facilities, of the Division of Animal Health from Massachusetts Department of Agricultural Resources Three Major Components of Biosecurity are confirmed: Isolation, Traffic control and sanitation. Key farm management practices prevent or reduce the following hazards to acceptable levels:

Biological Hazards-You should have a plan for controlling risk from viruses, bacteria, parasites and other contaminants. These controls must be considered from the standpoint of: 1. Introduction to the farm; 2. Exposure within and spread within the herd, 3. General and specific measures for immunization; 4. Minimizing the risk of export to other farms. 
Chemical Hazards-You should have a plan for handling and storage of pesticides, herbicides, feed additives, drugs, medicines and any potential toxic materials.

Physical Hazards - You should have a plan for animal handling and treatment to minimize trauma and maximize comfort and care. This includes ventilation, traffic flow, housing faclities and animal handling equipment.

\section{REFERENCES}

[1] Anderson, Neil G. (2011): Biosequrity: Health Protection and Sanitation Strategies for Cattle and General Gudelines for Other Livestock, Ministry of Agriculture Food \& Rural Affairs, Ontario, Canada.

[2] Australian Dairy Industry (2003): Biosecurity Plan, Version 1, June, 2003.

[3] Hristov, S., Stanković, B., Joksimović-Todorović, Mirjana, Davidović, Vesna (2007): Biosecurity measures on cattle farms. Welfare of Farms Animal and Biosecurity on Farms. Monography, Belgrade, Vol. 1, pp. 259-269.
[4] MA Department of Agricultural Resources, Division of Animal Health, Biosequrity for Dairy Facilities, Animal Health Information, 2010.

[5] Nitovski, A., Milenković, M., Grčak, Dragan, Radović, Bisa, Jotanović, Stoja, Milanović, Valentina, Vukasinović, S. (2011): Biosecurity Measures on Assessment and Cow Farms, Research people and actual tasks on multidisciplinary sciences, Proceedings of the Third International Conference, Lozenets, Bulgaria, 8-10. June, 2011, Volume 1, p. 232-235.

[6] Ordinance on determining the program of animal health protection measures for 2012. year, Official Gazete of the Republik Serbia, N ${ }^{\circ}$. 21/12.

[7] Ordinance on veterinary sanitation facilities for breeding of ungulate, ungulates, birds and rabbits, Official Gazette of the Republic of Serbia, $\mathrm{N}^{\circ} .81 / 2006$.

[8] Standards of biosecurity on farms. Basic setting biosecurity plans, brochure - Ministry of Agriculture, Trade, Forestry and Water Management for Animal Health.

[9] Stanković, B., Hristov, S., Zlatanović, Z. (2010): Biosecurity plans development on dairy and swine farms, Zbornik naučnih radova Instituta PKB Agroekonomik Belgrade, Vol. 16, br. 3-4, pp.125-132. 
Maced. J. Anim. Sci., 3 (1) 17-20 (2013) 